\title{
The Influence of Student Background Characteristics on Proficiency in English as a foreign language: Indonesian Context
}

\author{
Ratna Rintaningrum \\ Carol Aldous. \\ Institute of Technology Sepuluh Nopember, Indonesia. Email : rintaningrum@yahoo.com.au \\ John P Keeves \\ Flinders University, South Australia. Email: carol.aldous@ flinders.edu.au \\ University of Adelaide, South Australia.
}

Diterima: 17 November 2017

Direview: 27 November 2017

Diterbitkan: 30 November 2017

Hak Cipta @ 2017 oleh Penulis (dkk) dan Jurnal Sosial Humaniora (JSH)

*This work is licensed under the Creative

Commons Attribution International License (CC

BY 4.0).

http://creativecommons.org/licenses/by/4.0/ Open Access
Subject Areas: Linguistics

\begin{abstract}
In order to explain differences in English proficiency level, one needs to consider a number of factors frequently considered important at a variety of level of education systems. Among the factors that operate to influence English Foreign Language Proficiency are those associated with the student background variables. This study identifies the student level factors that influence English Foreign Language Proficiency. It is expected that this study can contribute to the development of a theory of foreign language learning that applies to students studying the English language at other universities in Indonesia and South-East Asia. This study involves the employment of an exploratory approach for the examination of the relationships between variables operating at the student level. Data are analyzed using Partial Least Squares Path Analysis (PLSPATH) to identify in an exploratory way the variables that have significant direct and indirect effects on English Foreign Language Proficiency. The study shows that a number of student background characteristics such as sex of student (GENDER), socioeconomic of student (SES), Faculty of Instruction (FACULTY), score of English 1 (ENGLISH_1) and semester in which students enrol in English 2 (SEMESTER) have only direct effects on English Language Proficiency, while student prior achievement (PRIOR) has both direct and indirect effects on English Foreign Language Proficiency.
\end{abstract}

Keywords: Student level variables, Proficiency, Foreign Language, Partial Least Squares Path (PLSPATH) Analysis.

\section{Introduction}

Access to tertiary education and the ability to communicate in the global language, namely English, is becoming increasingly significant in an ever expanding technological age. This situation is nowhere more important than in a developing country such as Indonesia where the nation's wealth depends for its growth and success on the production of a welleducated workforce who can engage with proficiency in a global dialogue which is conducted largely in English. Currently access to tertiary education in Indonesia is available for some, but not all, and even those who have access are not necessarily leaving university as proficient users of the English language in all its aspects, namely, reading, writing, listening, and speaking in English.

This suggests that different students through different methods of selection have in Indonesia, at the 
time of entry, have very different levels of skill in acquired proficiency in English. This information is readily available since it relates to the results on the English Language Proficiency Tests (ELPT) conducted before commencing at the university. There are many reasons why some students perform better in the use of the English language than others. This indicates that a number of very different factors can influence student proficiency and entry to the university. The effects of these different factors need to be investigated in this study.

There is a large body of research findings into such factors at the school level (Carhill, SuarezOrozco, \& Paez, 2008; Collins, 2000; Commonwealth of Australia, 2002; Considine \& Zappala, 2002; Henderson, 2002; Hungi, 2003; Pallardi \& Rumberger, 2002; Rothman, 1999). These results of prior research at the school level show that both student and school factors influence student achievement in English language performance with respect to reading (Adams \& Wu, 2002; Alderson, 2000; Elley, 1989, 1994; Kobayashi, 2002; Kotte, 2006; Lesaux, Lipka, \& Siegel, 2006; Lietz, 1996; OECD, 2001, 2003b; Purves, 1973; Rintaningrum, 2007, 2009; Shiotsu \& Weir, 2007), and to listening comprehension (Carter \& Nunan, 2001; Chastain, 1988; Cortazzi \& Jin, 1996; Elkhafaifi, 2005; Ling, 2008; Morley, 1991). However, little is known about the factors that operate at the university level to influence the learning of English in Indonesian universities or in universities in other Asian countries. Therefore, it is necessary to investigate the factors that influence success in learning English as a foreign language in Indonesian universities, since in Indonesia there is a lack of research in the field of foreign language learning, particularly at the university level. Information about the specific situation is urgently required. Some studies sought to obtain opinion but did not undertake quantitative research. Lauder (2008, p. 10) has said very succinctly "there are relatively few 'hard' facts".

\section{Review of the Literature}

\section{Student Level Factors Influencing Proficiency in English}

\section{The Effects of Chronological Age in Language}

\section{Acquisition}

Snow and Hoefnagel-Hohle (1978) conducted a study monitoring the progress of students who were newly-resident in the Netherlands and had begun learning Dutch. A few months after arrival, older students outperformed the younger students in the development of the new language. However, within about a year, younger students were able to surpass the level of performance of the older students. This suggested that further research was needed to identify the factors that might mediate the effects of age in the process of language acquisition. The research findings indicated that students' language skills continued to develop throughout middle and high school (Nippold, 1998). Unfortunately, as grade level increased, their proficiency had been shown to decline at relatively the same age as native speakers of English (Hakuta, Butler, \& Witt, 2000; Saunders \& O'Brien, 2006).

\section{The Effect of Gender}

Studies about understanding gender differences in educational performance have become of increasing interest. The concern with gender differences in foreign language learning, in particular, is linked to evidence from the results obtained from a variety of international and local assessment programs of reading literacy. Children consistently showed gender differences in the subject, favouring female students 
(Elley, 1994; Masters, 1997; Mullis et al., 2003; OECD, 2001).

Brain research on male and female students had helped explain differences in how modes of information processing developed (Tyre, 2005). The findings of biological research were "increasingly shedding light on neurological and hormonal differences in the brains of males and females" (Nyikos, 2008, p. 74). Legato (2005a) pointed out that the result of brain scan imagery studies undertaken by neuroscientists showed that to process language, females utilized the same area of the brain as males, however, depending on the linguistic task, women often used both sides of the brain, and when given the same tasks, women activated more areas in their brain than men did. Research has also reconfirmed that girls had "language centres" that matured earlier than those of boys (Tyre, 2005, p. 59).

ACER has reported that in all locations (Australian Geographic Category: Major Cities Australia, Inner Regional Australia, Outer Regional Australia and Remote/Very Remote Australia) females achieved higher mean scores on the PISA reading literacy assessment than did males (Cresswell \& Underwood, 2004). Consequently gender differences in reading achievement would not appear to be a result of living in urban, as contrasted to rural areas.

Walker (1976) reported findings from the IEA Six Subject Study that sex differences in performance on reading comprehension tests, were in general, slight although girls in a majority of countries performed better than boys. However, the initial PISA results showed a pattern of gender differences that was consistent across countries. In every country, on average, girls reached a higher level of performance than boys (OECD, 2001). Moreover, recent work by
Lietz (2006) has suggested that there were aspects of these studies that warranted further critical examination, with respect to gender references.

\section{Socio-Economic Status and Home Background}

Dixon, Zhao, Shin, Wu, Su, Burgess-Brigham, Gezer and Snow (2012, p. 39) indicated that optimal condition for foreign language learners in the L2 context were influenced by higher family SES, parent and grandparent education as well as strong home literacy practices. Previous research has shown that there was a relationship between parental education and the development of academic foreign language proficiency (Entwisle \& Anstone, 1994; Hakuta et al., 2000). This was because the more educated parents, the stronger language environments they provided at home, that were not greatly different from the language environment provided at school (Dickinson \& Tabors, 2001). In particular, there was a clear link between the level of maternal education and language development. Children and youth of more educated mothers were exposed to more an academically oriented vocabulary and were read to more often, may be regularly, from books that were valued in school (Goldenberg, Rueda, \& August, 2006).

This could be done by encouraging children to read together at home and generating family reading situations in order to help children to enhance their language development. Another more interesting reason was because learning to read and write a language began long before children in higher status homes entered school. Therefore, the engagement of parents or caregivers through activities provided children with a strong language environment that supported language and literacy development (Heath, 1983; Snow, Burns, \& Griffin, 1998). The involvement of parents and caregivers in literacy 
activities carried out either at home or at school was defined as 'family literacy programs' (Hannon, 2003). Recent research conducted by van Steensel, McElvany, Kurvers, and Herppich (2012, p. 87) stated that "family literacy interventions seem to make a modest contribution to children's literacy skills".

\section{The Aims of this Study}

This study investigates a set of issues associated with the provision and conduct of education in an Indonesian university in which it is necessary to facilitate the learning of English as a foreign language through a supplementary program. In particular, the complex relationships, arising between a set of issues involved in the learning of English as a foreign language at an engineering university in Indonesia are examined. These issues involve factors associated with age of student, sex of student, students' prior achievement, and the learning that occurs in English as a foreign language.

\section{Research Question to be Investigated}

The following question is advanced in order to achieve the main objectives of the study.

(1) What factors can be expected to have direct and indirect effects on the learning of English Foreign Language Proficiency at University?

\section{Location of Study}

In this study, access to the data and information is provided by an engineering university in Indonesia where this study is conducted.

\section{Method and Procedure}

This study employs Partial Least Squares Path Analysis (PLSPATH) (Sellin, 1990) to identify in an exploratory way the variables that have significant direct and indirect effects on English Language Proficiency. Therefore, it is first necessary to consider the construction of a model that examines the relationships between the causal factors that influence English Language Proficiency.

Models of the student level factors influencing student proficiency in English examined in this study are developed from the findings of previous studies and knowledge of the context. However, the factors are limited to those with data recorded in the university database. Since the nature of the models proposed in this study is exploratory, many variables that are likely to have an influence on student achievement in English are hypothesized in the models. The aim of exploration is to identify what are the significant factors at the student level that affect students' performance in English. Consequently, consideration of an appropriate exploratory multivariate technique to analyze the models is required. In order to examine causal relationships, such as the ones proposed in this study, the Partial Least Squares Path Analysis (PLSPATH 3.1) program is widely used as an exploratory technique (Sellin \& Keeves, 1994).

\section{Source of Information and Data \\ University Data Files}

Data employed in this study are secondary data taken from the University archives and are used in subsequent analyses in this study. These data are obtained from three sources in the University under survey. The three sources of data that are used in this study: (a) the University Academic Bureau, (b) the Language Centre, and (c) the Language Laboratory samples drawn from the target population. 


\section{Population for Secondary Data}

The available population for this study is (a) all undergraduate students, (b) who enrol in the advanced English (English 2 course) and have undertaken the English 2 final test (c) at the University involved, (d) during the period 2007-2009. There are about 5597 students who form the population available. This is referred to as the register sample.

\section{Dataset Used in this Study}

However, the models examined in this study are tested using one large dataset that is separated into two main data files. The separation of the dataset is carried out because there are several variables of interest that have considerable missing data. In order that the data can be subjected to the statistical analyses, the decision is made to separate the original large dataset into two main data files.

This problem arises because in the recording of the data that forms the variable English Language Proficiency Test (ELPT), both IRT-scaled scores with a mean of 50 and a standard deviation of 10 , as well as Grade-scaled scores are employed. However, for approximately half of the sample of 5000 students who completed the course with a Grade Point Average the
Grade-scaled scores for ELPT ranging from 1 to 4 are recorded, and the IRT-scaled scores are not recorded on the University files.

For the other half of the sample both sets of scores are recorded. Thus two overlapping samples can be formed, namely: (a) those students who have only Grade-scaled scores for ELPT; and (b) those students who have both Grade-scaled scores and IRT-scaled scores. Moreover, both groups of students have some data missing on other variables that are being employed in these analyses. Under these circumstances a decision is made to refrain from using any imputation procedures for the replacement of missing data on all variables involved in the analyses or to use pairwise procedures in the calculation of correlations, but to employ the listwise procedure (Hair, Tatham, Anderson, Black, 2006). As a consequence there are considerable losses of cases in both groups (a) and (b). Group (a) has complete data for 1978 cases and Group (b) has complete data for 3995 cases. Group (a) forms approximately 40 per cent, and Group (b) forms approximately 80 per cent of the initial number of cases in the original dataset. The treatment of the data to be used in the study is illustrated in Figure 1.

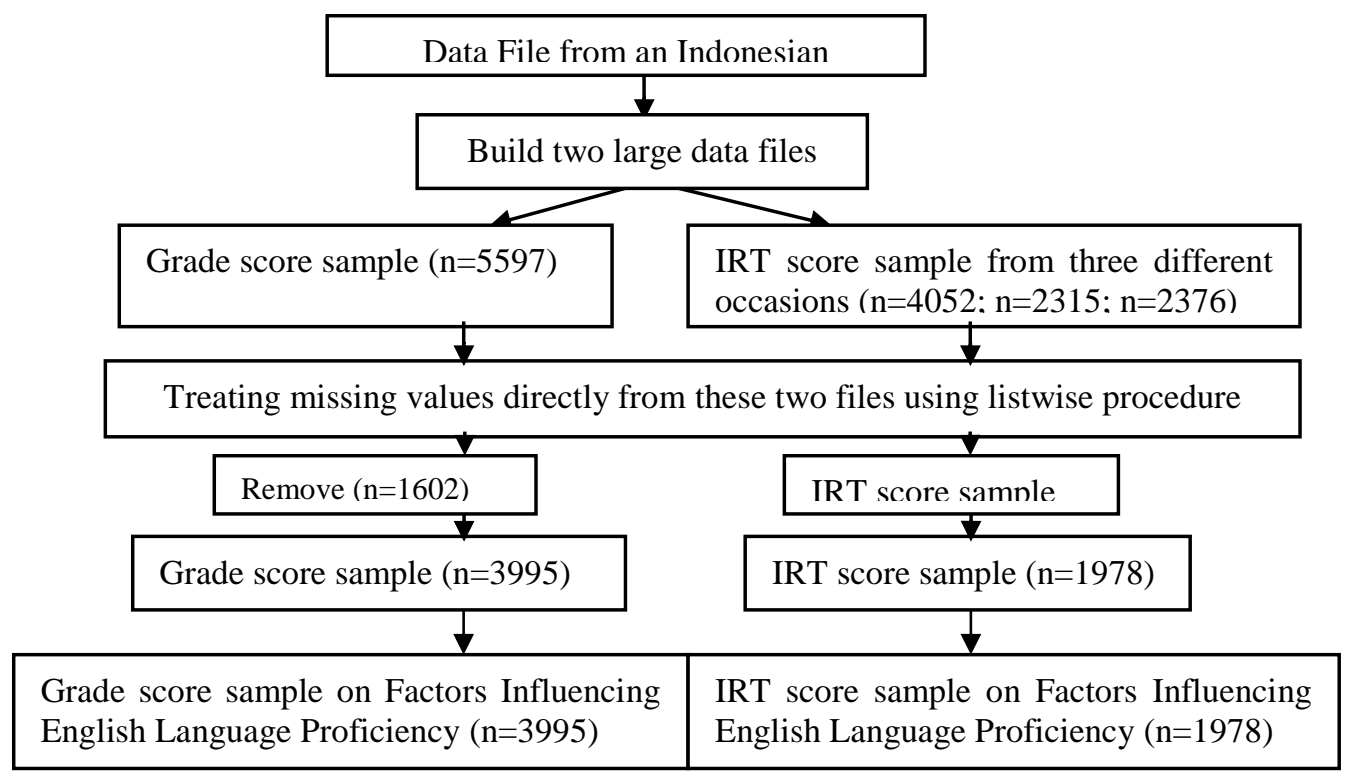

Figure 1: Data Design 


\section{Variables Included in the PLSPATH Analysis}

Table 1 records latent and manifest variables included in the PLSPATH analysis. Table 1 shows a list of variables operating at the student level. Both variable names and their acronyms are recorded for the latent variables and the manifest variates involved. For two of the latent variables, namely, SES and PRIOR the outward mode is necessarily employed since these variables are reflected by the manifest (observed) variates that are involved. The variables GENDER, AGE, FACULTY, SELECT, ENGLISH_1, YEAR, BAHASA, SEMESTER, and ENGLISH_2 are all in the unity mode. Student-Level Model of English Foreign Language Proficiency

Figure 2 shows that there are nine variables hypothesized to influence English Language Proficiency (ENGLISH_2), namely sex of student
(GENDER), age of student at the beginning of the course (AGE), socio-economic status (SES), student's prior achievement (PRIOR), faculty in which students study (FACULTY), method of student selection (SELECT), English 1 score (ENGLISH_1), Bahasa score (BAHASA), and the semester in which the students enrolled in English 2 (SEMESTER). In the path models, all these variables are treated as latent variables (LVs), and in this study all variables are reflected by one or more manifest variates (MVs). There are only two latent variables that are reflected by more than one manifest variate, namely socioeconomic status (SES) and achievement before entering university (PRIOR). Table 1 records ten scaled variables that are included in the analysis, together with the coding of the categories.

\begin{tabular}{|c|c|c|c|c|c|}
\hline Latent Variable & Manifest Variate & & Source & Coding & Mode \\
\hline (Acronym) & Acronym & Description & & & \\
\hline $\begin{array}{l}\text { Sex of Student } \\
\text { GENDER }\end{array}$ & Sex & Sex of student & File & $\begin{array}{l}0=\text { male }, \\
1=\text { female }\end{array}$ & Unity \\
\hline $\begin{array}{l}\text { Time_Begin } \\
\text { AGE }\end{array}$ & Time_Begin & $\begin{array}{l}\text { Age at the beginning } \\
\text { of the course }\end{array}$ & File & $\begin{array}{l}\text { Rank-scaled } \\
\text { score }\end{array}$ & Unity \\
\hline $\begin{array}{l}\text { Socio-economic Status } \\
\text { SES }\end{array}$ & $\begin{array}{l}\text { Focc } \\
\text { Mocc } \\
\text { Psal } \\
\end{array}$ & $\begin{array}{l}\text { Father Occupation } \\
\text { Mother Occupation } \\
\text { Parent Salary } \\
\end{array}$ & File & $\begin{array}{l}\text { Criterion } \\
\text { Scaling } \\
\text { Rank-scaled } \\
\text { score } \\
\end{array}$ & Outward \\
\hline $\begin{array}{l}\text { Prior Achievement } \\
\text { PRIOR }\end{array}$ & $\begin{array}{l}\text { Physic } \\
\text { Math } \\
\text { English } \\
\end{array}$ & $\begin{array}{l}\text { Physics Score } \\
\text { Mathematics Score } \\
\text { English Score }\end{array}$ & File & $\begin{array}{l}\text { Continuous } \\
\text { score }\end{array}$ & Outward \\
\hline $\begin{array}{l}\text { Faculty } \\
\text { FACULTY }\end{array}$ & Faculty & $\begin{array}{l}\text { Faculty in which student } \\
\text { affiliates }\end{array}$ & & $\begin{array}{l}\text { Criterion } \\
\text { Scaling }\end{array}$ & Unity \\
\hline $\begin{array}{l}\text { Mode of Selection } \\
\text { SELECT }\end{array}$ & Selection & $\begin{array}{l}\text { Method of Student } \\
\text { Selection }\end{array}$ & File & $\begin{array}{l}\text { Criterion } \\
\text { Scaling }\end{array}$ & Unity \\
\hline $\begin{array}{l}\text { English_1 } \\
\text { ENGLISH_1 }\end{array}$ & Score Eng_1 & English_1 Score & File & $\begin{array}{l}\text { Rank-scaled } \\
\text { score }\end{array}$ & Unity \\
\hline $\begin{array}{l}\text { Year } \\
\text { YEAR }\end{array}$ & Year & $\begin{array}{l}\text { Year in which students } \\
\text { enrolled in Bahasa }\end{array}$ & File & $\begin{array}{l}\text { Rank-scaled } \\
\text { score }\end{array}$ & Unity \\
\hline $\begin{array}{l}\text { Bahasa Indonesia } \\
\text { BAHASA }\end{array}$ & Score_BAH & Bahasa Score & File & $\begin{array}{l}\text { Rank-scaled } \\
\text { score }\end{array}$ & Unity \\
\hline $\begin{array}{l}\text { Semester } \\
\text { SEMESTER }\end{array}$ & Semes & $\begin{array}{l}\text { Semester in which } \\
\text { students took English_2 }\end{array}$ & File & $\begin{array}{l}\text { Rank-scaled } \\
\text { score }\end{array}$ & Unity \\
\hline $\begin{array}{l}\text { English Proficiency } \\
\text { ENGLISH_2 }\end{array}$ & ENG_Proficiency & English_2 Score & File & $\begin{array}{l}\text { Rank-scaled } \\
\text { score }\end{array}$ & Unity \\
\hline
\end{tabular}

Table 1 : Latent and Manifest Variables Included in Student Level Analysis 


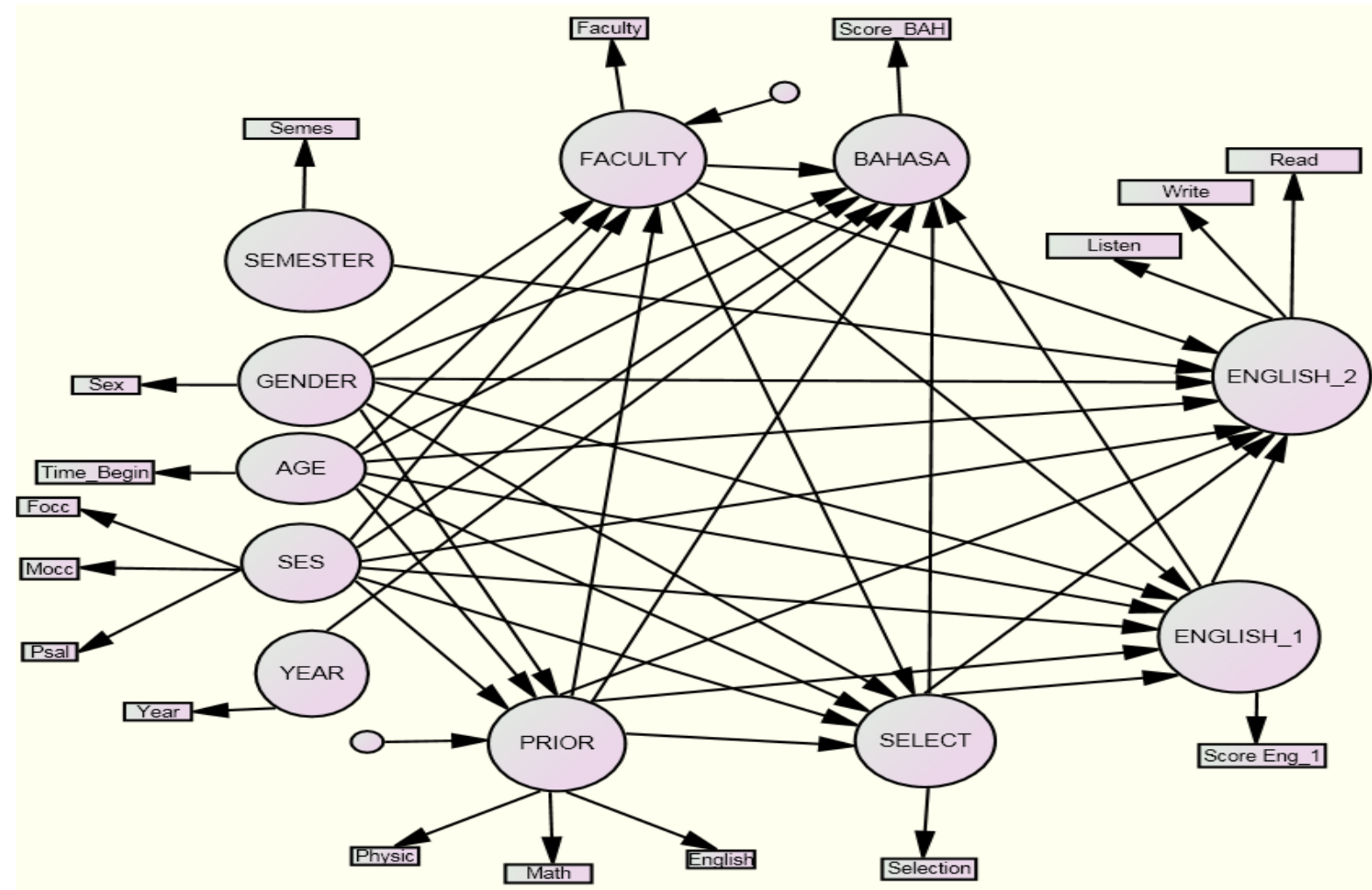

Figure 2 : Hypothesized Path Model with Latent Variables for the Exploratory Examination of English Proficiency

Therefore, in the examination of student level factors influencing student proficiency in English, there are 9 Latent Variables (LVs) and 13 Manifest Variables (MVs) presented in the path model.

\section{Results from the Student Level Factors Influencing English Language Proficiency}

The results of the PLSPATH final model follow and are reported for the results of the inner model analysis in Table 2.
Inner Model Results for the Student-level Factors Influencing English Language Proficiency: Results and Discussion

The inner model specifies the relationships between the latent variables (LVs) (Sellin, 1989). For the purposes of these analyses, the path coefficient of 0.07 is considered as the critical value to indicate a significant effect of one LV on another LV which it influences (Sellin, 1989). This critical value is chosen to be greater than twice the largest estimated standard error in the path analyses, in order to make allowance for the clustering of students in faculties which cannot be provided for the estimation of the path coefficients. 


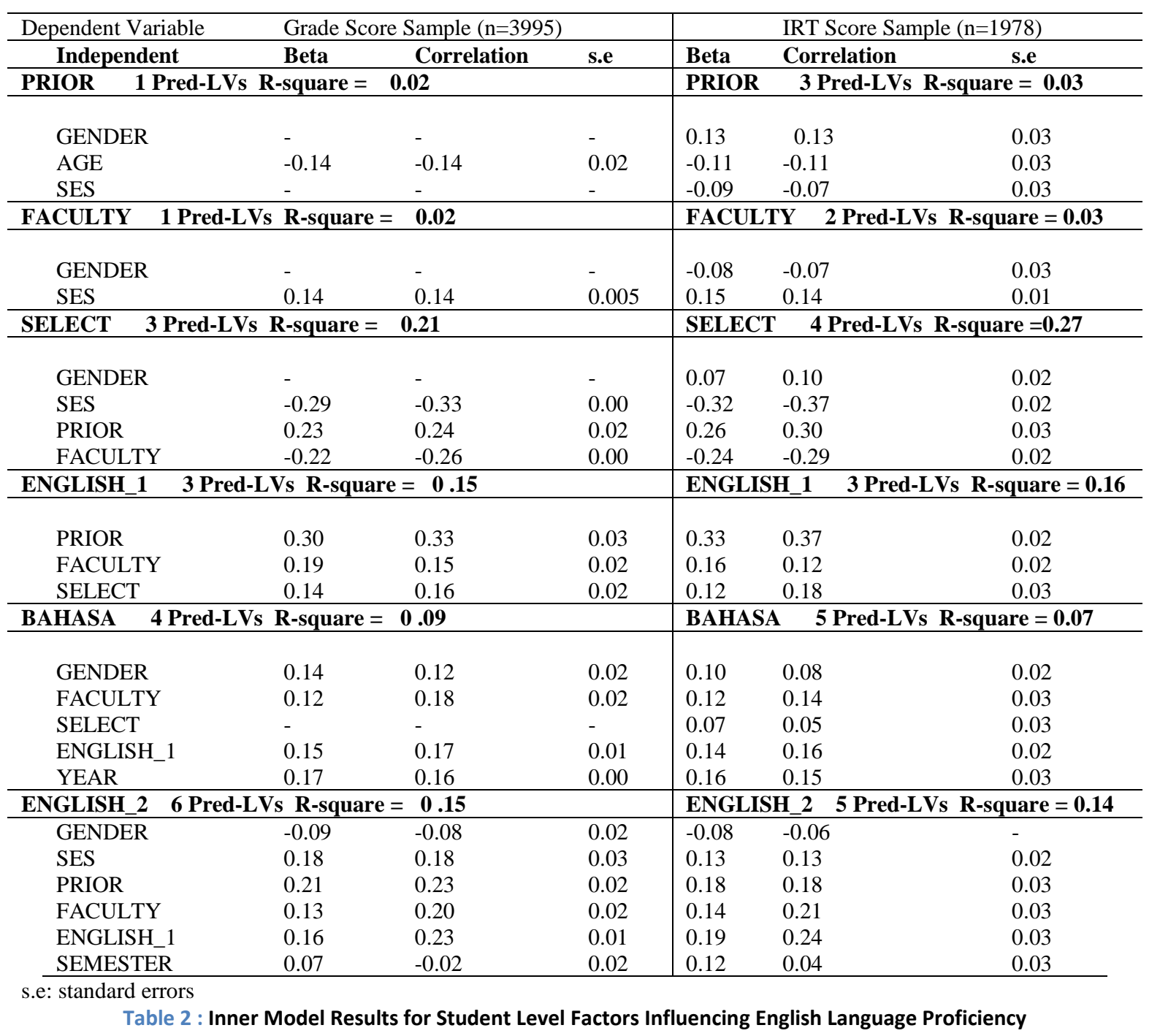

The path coefficient for the inner model results are calculated only for the endogenous latent variables, namely latent variables which have arrows pointing to the latent variables concerned as are drawn in the path model in Figure 1 This model hypothesized that there are $11 \mathrm{LVs}$ in the model, five of them are endogenous (PRIOR, FACULTY, SELECT, BAHASA, and ENGLISH_1), while five others are antecedents or exogenous LVs (GENDER, AGE, SES, YEAR, and SEMESTER) and the LV ENGLISH_2 is the criterion variables. For this reason, the results of the analyses in the section that follows are presented for the five endogenous LVs only. The revised path diagram for the student level factors influencing English Language Proficiency (ENGLISH_2) is presented in Figure 3 


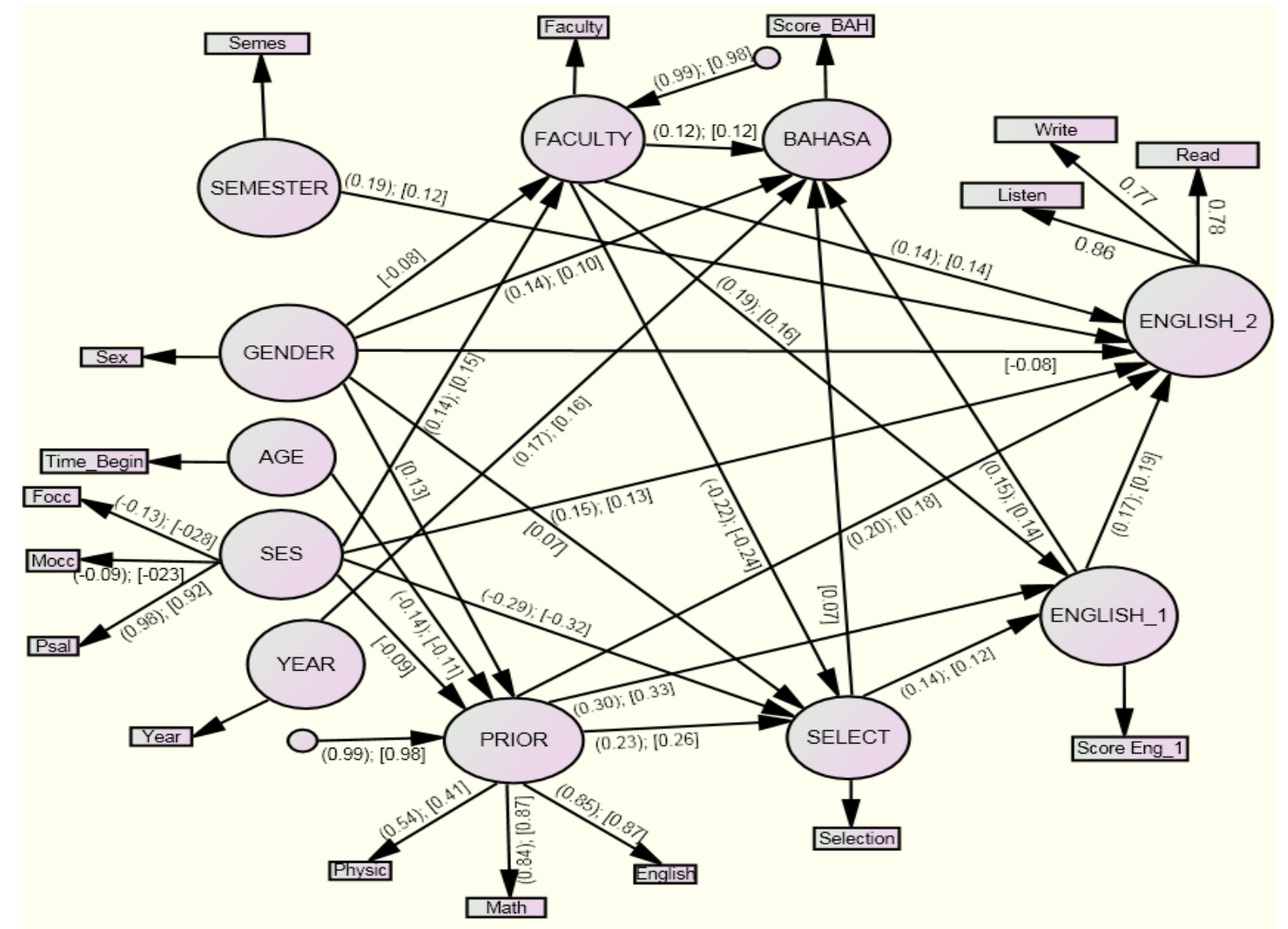

Figure 3 : The student level factors influencing English Language Proficiency

In the proposed model presented in Figure 2, prior achievement (PRIOR) is hypothesized to be influenced by three other latent variables, namely GENDER, AGE, and SES. The results of the analysis indicate that the variable AGE has effects with $\beta=$ $0.14(0.02)$ in the Grade score sample and $\beta=-0.11$ (0.03) in the IRT score sample, with a greater effect in the Grade score sample. The negative sign indicates that younger students are more likely to have higher levels of prior performance than the older students.

The variable GENDER has only a significant positive effect for the IRT score sample with $\beta=0.13$ (0.03) indicating that girls are more likely to have in general, higher scores on the prior performance variable of the Mathematics, Physics, and English scores. It is interesting to note that for the variable SES significant effects are recorded only for the IRT score sample but the effect is small with $\beta=-0.09(0.03)$ with the negative sign indicating that the students from low socio economic status homes are more likely to have higher prior achievement in the IRT score sample. Prior achievement is the students' level of achievement obtained before they enter the University, and it is not surprising that this variable is related to the mode of student selection for both samples with $\beta=$ $0.23(0.02)$ and $\beta=0.26(0.03)$ for the Grade score sample and IRT score sample respectively. Moreover, the variable of student selection, following the results of criterion scaling shows that students who enter the University under Scholarship and Achievement, combined with Other procedures, have the highest mean scores for the GPA (3.25) and English Language Proficiency (2.91). Thus, students who enter to the University under the Scholarship and Achievement (Other) procedures tend to be from a lower socioeconomic background.

Therefore, this argument explains why the relationship between SES and PRIOR is negative. This 
indicates that students from lower socio-economic backgrounds enter the University under scholarship procedures and have better prior achievement.

\section{Faculty of Instruction (FACULTY)}

There are five faculties involved in the study, namely, Marine Engineering, Mathematics and Natural Sciences, Civil and Planning Engineering, Industrial Engineering, and Informatics System Engineering. The LV FACULTY is categorical in nature. From Table 2 following criterion scaling, the Faculty of System Informatics Engineering is found to have the highest level mean score, followed by Industrial Engineering, Civil and Planning Engineering, Mathematics and Natural Sciences, and Marine Engineering has the lowest mean score.

In the path model, Faculty of instruction (FACULTY) is hypothesized to be influenced by four LVs, namely GENDER, AGE, SES, and PRIOR. The results of the analysis indicate that Socio-economic Status has a significant effect on the choice of Faculty with a path coefficient of $0.14(0.005)$ for the Grade score sample and $0.15(0.01)$ for the IRT score sample. This indicates that the Socio-economic Status of parents has an effect on how students choose the faculty in which they enrol. It is found that Parent Salary (Psal) is the strongest variate for the Socioeconomic Status (SES) variable. This is because Parent Salary (Psal) has the largest factor loading in reflecting SES. This indicates that students whose parents are richer are more likely to choose a course like Informatics System Engineering and Industrial Engineering, while students from low income homes are more likely to choose Marine Engineering. In addition, for the IRT score sample GENDER has a significant effect with a negative path coefficient $(\beta)$ of $-0.08(0.03)$ indicating that boys are also more likely to select courses like Informatics System Engineering and Industrial Engineering.

\section{Method of Student Selection (SELECT)}

The University under survey has several different methods of student selection, including national selection and local selection. The local selection method has four different modes of selection, namely Invitation, Scholarship, Achievement, and Partnership. Students who enter the University by choosing 'partnership' as their method for entering the university are required to pay more than required by other methods of selection. Partnership means that the University collaborates with some industrial sectors and allows the students to enter the University by taking a local university test, but the student is required to pay more in fees.

In the proposed model presented in Figure 2, mode of selection (SELECT) is hypothesized to be influenced by five LVs, namely GENDER, AGE, SES, PRIOR and FACULTY. The results of analysis indicate that out of these five LVs, four LVs, namely GENDER, SES, PRIOR and FACULTY have significant effects on the criterion scaled variable SELECT. However, GENDER has an effect only on SELECT for the IRT score sample with $\beta=0.07(0.02)$. The positive sign indicates that method of selection is influenced more by being a female student than by being a male student in the IRT score sample. However, Socio-economic status (SES) has similar effects for both samples with path coefficients of $\beta=$ $0.29(0.00)$ and $\beta=-0.32(0.02)$ for the Grade and IRT score samples respectively. This indicates that the Socio-economic Status of the parents has an effect on the ways in which students choose the method of selection offered by the University with lower income families relying on scholarships and achievement. 
The LV PRIOR also has a significant effect on SELECT with similar path coefficient for both samples of $\beta=0.23(0.02)$ and $\beta=0.26(0.03)$ for the Grade and IRT score samples respectively. This indicates that the level of prior achievement obtained by students influences the selection method by means of which students are able to attend the University. The positive sign indicates that students who have a higher level of Prior Achievement are more likely to attend the University with a scholarship and less likely through an industrial partnership.

FACULTY is the fourth LV that has a significant effect on SELECT with $\beta=-0.22(0.00)$ for the Grade score sample and $\beta=-0.24(0.02)$ for the IRT score sample. The negative sign indicates that students who choose the Faculty of System Informatics Engineering are more likely to be students who enter the University with a scholarship and a higher level of Academic Achievement. This also implies that students who attend the University under Industrial Partnership selection are less likely to be chosen by the Faculty of Informatics Engineering. The criterion scaling procedure indicate that students who attend the University under Industrial Partnership have the lowest mean score compared to students who attend the University by other modes of student selection. Moreover, students who choose the Faculty of Informatics Engineering are more likely to have higher achievement as is indicated by the highest mean score in their academic performance. The results in Table 2 also indicate that the variance explained of SELECT for the Grade score sample 21 per cent and for the IRT score sample is 27 per cent, which indicates that the residual paths shown in Figure 3 for SELECT are 0.89 and 0.85 respectively. It can be concluded from these results that for SELECT, Socio-economic Status has the strongest total effect on method of student selection ( $\beta=-0.29$ for Grade score sample) and $(\beta=$ 0.32 for the IRT score sample).

The results of inner model indirect effects are also recorded in Table 3. Indirect effects are only discussed for those LVs that have an effect of $i=0.06$ or larger. Table 3 indicate that the LV SES has marginal indirect effect on SELECT with an indirect path coefficient of -0.06 . This effect only applies for the IRT score sample. For the Grade score sample, the LVs AGE and SES also have indirect effects on SELECT, but the effects are very small, and fall well below 0.06. Socio-economic Status (SES) has the small indirect effect on method of student selection (SELECT) because of its effects on student Prior Achievement (PRIOR) of -0.09 and FACULTY of 0.15 which in turn have effects on method of student selection (SELECT).

\section{Score of English 1t (ENGLISH_1)}

Students were enrolled in English 1c at the beginning of the University course. In this study, the LV ENGLISH_1 that indicates the language achievement score of English 1t obtained at the beginning or during of Course 1 . Table 2 records that three latent variables (LVs) namely student Prior Achievement (PRIOR), Faculty of Instruction (FACULTY), and mode of Student Selection (SELECT) have effects on the score of English 1t and explain 15 per cent and 16 per cent of the variance for the Grade score sample and IRT score sample respectively. Student Prior Achievement (PRIOR) has similar effects on both Grade score and IRT score samples with $\beta=0.30(0.03)$ and $\beta=0.33(0.02)$ respectively. These indicate that students who have a higher level of Prior Achievement are more likely to do better in English 1t. The second LV which has significant effects on ENGLISH_1 is FACULTY with 
$\beta=0.19(0.02)$ for Grade score sample and $\beta=0.16$ (0.02) for IRT score sample. The results of scaling recorded in a separate analysis indicate that students who are from Informatics System Engineering are likely to be the better performers than students from other faculties. In addition, the effects of method of selection (SELECT) are 0.14 (0.02) and 0.12 (0.03) for the two samples of Grade and IRT score samples respectively on ENGLISH_1 indicate that students who enter the University under the scholarship procedure are more likely to perform better in English 1t than students under other methods of student selection. There are several small indirect effects that are recorded in Table 3 operating to influence ENGLISH_1 performance but they all fall below the level of $\mathrm{i}=0.06$ for any discussion or consideration of their influence.

\begin{tabular}{|c|c|c|c|c|c|c|}
\hline \multirow{2}{*}{$\begin{array}{c}\text { Dependent Variable } \\
\text { Independent }\end{array}$} & & \multicolumn{2}{|c|}{3995 cases } & \multicolumn{3}{|c|}{1978 cases } \\
\hline & Direct & Indirect & Total & Direct & Indirect & Total \\
\hline PRIOR $\quad$ R-square $=0$. & 0.02 & & & \multicolumn{3}{|c|}{ R-square $=\mathbf{0 . 0 3}$} \\
\hline GENDER & - & - & - & 0.13 & - & 0.13 \\
\hline AGE & -0.14 & - & -0.14 & -0.11 & - & -0.11 \\
\hline SES & - & - & - & -0.09 & - & -0.09 \\
\hline FACULTY R-square = & $\mathbf{0 . 0 2}$ & & & \multicolumn{3}{|c|}{ R-square $=0.03$} \\
\hline GENDER & & & & -0.08 & - & -0.08 \\
\hline SES & 0.14 & - & 0.14 & 0.15 & - & 0.15 \\
\hline SELECT $\quad$ R-square = & 0.21 & & & \multicolumn{3}{|c|}{ R-square $=0.27$} \\
\hline GENDER & - & - & & 0.07 & - & 0.12 \\
\hline AGE & - & -0.03 & -0.032 & - & - & -0.03 \\
\hline SES & -0.29 & -0.03 & -0.32 & -0.32 & -0.06 & -0.38 \\
\hline PRIOR & 0.23 & - & 0.23 & 0.26 & - & 0.26 \\
\hline FACULTY & -0.22 & - & -0.22 & -0.24 & - & -0.24 \\
\hline ENGLISH_1 $\quad$ R-square = & $=0.15$ & & & \multicolumn{3}{|c|}{ R-square $=0.16$} \\
\hline GENDER & - & - & - & - & 0.04 & 0.04 \\
\hline AGE & - & -0.05 & -0.05 & - & -0.04 & -0.04 \\
\hline SES & - & -0.02 & -0.02 & - & -0.05 & -0.05 \\
\hline PRIOR & 0.30 & 0.03 & 0.33 & 0.33 & 0.03 & 0.37 \\
\hline FACULTY & 0.19 & -0.03 & 0.15 & 0.16 & -0.03 & 0.13 \\
\hline SELECT & 0.14 & - & 0.14 & 0.12 & - & 0.12 \\
\hline BAHASA $\quad$ R-square $=0$ & 0.09 & & & \multicolumn{3}{|c|}{ R-square $=0.07$} \\
\hline GENDER & 0.14 & - & 0.14 & 0.10 & 0.01 & 0.10 \\
\hline AGE & - & -0.01 & -0.01 & - & -0.01 & -0.01 \\
\hline SES & - & 0.01 & 0.01 & - & -0.02 & -0.02 \\
\hline PRIOR & - & 0.05 & 0.05 & - & 0.07 & 0.07 \\
\hline FACULTY & 0.12 & 0.02 & 0.14 & 0.12 & 0.00 & 0.07 \\
\hline SELECT & - & 0.02 & 0.02 & 0.07 & 0.02 & 0.12 \\
\hline ENGLISH_1 & 0.15 & - & 0.15 & 0.13 & - & $\begin{array}{l}0.14 \\
0.16\end{array}$ \\
\hline YEAR & 0.17 & - & 0.17 & 0.16 & - & \\
\hline ENGLISH_2 R-square = & $=0.15$ & & & \multicolumn{3}{|c|}{ ENGLISH_2 R-square $=0.14$} \\
\hline GENDER & -0.09 & - & -0.09 & - & 0.02 & 0.02 \\
\hline AGE & - & -0.04 & -0.04 & - & -0.03 & -0.03 \\
\hline SES & 0.18 & 0.02 & 0.19 & 0.15 & -0.01 & 0.14 \\
\hline PRIOR & 0.21 & 0.05 & 0.27 & 0.20 & 0.06 & 0.26 \\
\hline FACULTY & 0.13 & 0.02 & 0.16 & 0.14 & 0.02 & 0.16 \\
\hline SELECT & - & 0.02 & - & 0.02 & 0.02 & 0.02 \\
\hline ENGLISH_1 & 0.16 & - & 0.16 & 0.17 & - & 0.17 \\
\hline SEMESTER & 0.07 & - & 0.07 & 0.19 & - & 0.19 \\
\hline
\end{tabular}

Table 3 : Inner Model Effects for Student Level Factors Influencing English 2 Language Proficiency ${ }^{a}$

${ }^{\text {a }}$ Indirect effects in bold type are discussed in the text 


\section{Score of Bahasa Indonesia (BAHASA)}

The LV BAHASA involves the scores on Bahasa Indonesia. In the path model, there are five LVs (latent variables), namely, GENDER, FACULTY, SELECT, ENGLISH_1, and YEAR, that have effects on BAHASA scores. However, the LV SELECT only has a small effect on BAHASA for the Rasch score sample with a beta coefficient of $\beta=0.07$ (0.03). Table 4 shows that students who attend the University under Scholarship Selection are likely to be better prior achievers than students under other methods of selection. The second LV which has effects on BAHASA is GENDER with $\beta=0.14$ (0.02) for the Grade score sample and $\beta=0.10(0.02)$ for the IRT score sample. This indicates that female students have higher levels of Bahasa Indonesia scores than their male counterparts. Moreover, FACULTY has effects on the LV BAHASA with a beta coefficient of $\beta=0.12(0.02)$ and $\beta=0.12(0.03)$ for the Grade score and the IRT score samples respectively.

Table 2 records that for the Faculty of Instruction, students who are from the Faculty of Informatics System Engineering are more likely to have the highest level on the Bahasa score tests. The variable ENGLISH_1 has similar total effects on BAHASA for both samples with $\beta=0.15(0.01)$ for the Grade score sample and $\beta=0.14(0.02)$ for the IRT score sample. This indicates that students who are good performers in ENGLISH_1 are more likely to do better in the BAHASA test. In addition, Table 2 also records that students who undertake BAHASA in the later years are more likely to have higher performance than students who undertake BAHASA in the earlier years with path coefficients of $\beta=0.17(0.00)$ and 0.16 (0.03) for the Grade score and the IRT score samples respectively.
It is interesting to note that Table 3 records that student Prior Achievement (PRIOR) has an indirect effect on BAHASA $(\beta=0.07)$ in part because of its effect on SELECT $(\beta=0.23)$ which in turn has an effect on BAHASA $(\beta=0.07)$. However, only small proportions of the Bahasa scores are explained by the two samples of 9 per cent and 7 per cent for the Grade score and the IRT score samples with residual paths of 0.95 and 0.96 respectively.

\section{Criterion Variables}

\section{Factors that Influence English Language} Proficiency (ENGLISH_2): Results and Discussion

It can be seen from Table 2 that six latent variables, namely sex of student (GENDER), Socioeconomic status (SES), student Prior Achievement (PRIOR), Faculty of Instruction (FACULTY), Score on English 1t (ENGLISH_1), and semester in which students undertook English 2c (SEMESTER) account for English proficiency (ENGLISH_2) and explain 15 per cent of the Grade score sample variance $(n=3995)$ and 14 per cent of the variance of the IRT score sample $(n=1978)$ in the English 2t score. The strongest effect is recorded for student performance before entering university (PRIOR) with path coefficient of $\beta=0.21$ (0.02) for Grade score sample and $\beta=0.18(0.03)$ for IRT score sample. This indicates that the better the student performs before entering the university, the more likely it is that they perform better on the English $2 t$ test. Conversely, those who have low achievement before entering the university tend to have lower performance on English 2t. A second LV which has an influence on English 2t is SEMESTER with beta coefficients of 0.07 and 0.12 for the Grade score and IRT score samples respectively. This relationship reveals that the earlier students enrol in English 2c, the better the students perform on English 2t. FACULTY 
also has a significant path in predicting English proficiency (ENGLISH_2) with path coefficients of $0.13(0.02)$ and $0.14(0.03)$ for the Grade score sample and the IRT score sample respectively indicating that students who study in the Faculty of Informatics System Engineering are likely to perform better in English 2t test than students who study in the other Faculties. Moreover, students who have higher scores in English 1 (ENGLISH_1) are more likely to perform better in English $2 \mathrm{t}$ with path coefficients of 0.16 (0.01) and 0.17 (0.03) for the Grade score sample and the IRT score sample respectively. This is in contrast to those students who do not have high language performance in English 1t. SES is the last LV that is also found to be a relatively strong predictor on English 2t with path coefficients of 0.18 (0.03) and $0.13(0.02)$ for the Grade score and the IRT score samples respectively. This indicates that students from higher financial status homes are more likely to achieve higher test scores on English 2t than students from lower status homes.

In addition to the direct effect presented in Table 2, Table 3 presents indirect and total effects on English Language Proficiency. The estimated indirect effects indicate the strength of the indirect relationship of a variable, namely, PRIOR (0.06) on English 2t scores (ENGLISH_2) for the IRT score sample. However, this effect results from the relationships of PRIOR on ENGLISH_1 $(\beta=0.30$ and $\beta=0.33$ for the Grade score and the IRT score samples respectively) which in turn have strong direct effects ( 0.16 and 0.19 respectively) on English 2t. Thus, PRIOR is found to have a significant indirect effect on ENGLISH_2 through ENGLISH_1 for the IRT score sample and a marginal indirect effect of 0.05 for the Grade score sample.

Prior Achievement (PRIOR) is the strongest predictor of English Language Proficiency (ENGLISH_2), while the LV FACULTY and English 1t have smaller influences on English Language Proficiency (ENGLISH_2). However, only 15 per cent and 14 per cent of the variance in the scores for the Grade score and the IRT score samples are explained respectively of ENGLISH_2 performance in this study with large residual paths of 0.93 and 0.92 respectively.

\section{Summary}

In summary, the results show that there are not large differences in the beta values between the results of inner model analyses for factors influencing English language proficiency (ENGLISH_2) measured with one manifest variate and English Language Proficiency (ENGLISH_2) measured with three manifest variates. The results indicate that the results are very similar. However, there are small differences in the number of factors that influence English language proficiency. The LV ENGLISH_2 with one manifest variate is influenced by five factors, namely, socio-economic status (SES), student prior achievement (PRIOR), Faculty of Instruction (FACULTY), score of English 1t (ENGLISH_1), and semester in which students undertake English 2c (SEMESTER). However, the LV ENGLISH_2 with three manifest variates is influenced by six factors, namely gender of student (GENDER), socioeconomic status (SES), student prior achievement (PRIOR), Faculty of Instruction (FACULTY), score of English 1 (ENGLISH_1), and semester in which students undertake English 2c (SEMESTER). The emergence of LV GENDER with an influence on English language proficiency (ENGLISH_2) with three manifest variates with $\mathrm{p}=-0.08$ provides more information on the factors that are hypothesized to have an influence on English language proficiency. Since the LV GENDER with respect to the 1 to 4 scale 
(English language proficiency with one manifest variate) only produces a path coefficient that is lower than $\beta=0.07$, and the LV GENDER is removed from the model.

\section{Recommendation}

Further investigation and analyses are needed for assessing, recording and developing English Foreign Language Proficiency in order that the teaching and learning of English (where the major is not learning the English language) can be effectively monitored and improved at the university.

\section{Appendix}

English 1c: English 1 course

English 1t: English 1 test

English 2c: English 2 course

English 2t: English 2 test

\section{References}

Adams, R., \& Wu, M. (2002). Program for International Student Assessment (PISA): PISA 2000 Technical Report. Paris: OECD.

Alderson, J. C. (2000). Assessing Reading. New York: Cambridge University Press.

Carter, R., \& Nunan, D. (2001). The Cambridge guide to teaching English to speakers of other languages. Cambridge. Cambridge University Press.

Carhill, A., Suarez-Orozco, C., \& Paez, M. (2008). Explaining English Language Proficiency Among Adolescent Immigrant Students. American Educational Research Journal, 45(4), 1155-1179.

Chastain, K. (1988). Developing secong language skills theory and practice. Florida: Harcourt Brace Jovanovich.

Collins, C., Kenway, J., \& McLeod, J (2000). Factors Influencing the Educational Performance of Males and Females in School and their Initial Destinations after Leaving School. (A Project Funded by the Commonwealth Department of Education, Training and Youth Affairs): Deakin University, University of South Australia.

Commonwealth Department of Education- Scienceand-Training and Department of Defence. (2002). Changing Schools: Its Impact on Student Learning. Retrieved February 11, 2007, from http:www.dest.gov.au/schools/publications/index .htm

Considine, G., \& Zappala, G. (2002). Factors Influencing the Educational Performance of Students from Disadvantage Background. In T. a. B. Eardley, B (Ed.), Competing Visions: Refered Proceedings of the National Social Policy Conference 2001, SPRC Report (Vol. 1, pp. 91107). Sydney: Social Policy Research Centre, University of New South Wales,.

Cortazzi, M., \& Jin, L. X. (1996). Cultures of learning: Language classrooms in China. In I. H. Coleman (Ed.), Society and the language classroom (pp. 169-206). Melbourne: Cambridge University Press.

Dickinson, D., \& Tabors, P. (2001). Beginning Literacy with Language: Young Children Learning at Home and School. Baltimore: Paul H. Brookes.

Dixon, L. Q., Zhao, J., Shin, J., Wu, S., Su, J., BurgessBrigham, R., et al. (2012). What We Know about Second Language Acquisition: A Synthesis from Four Perspectives. Review of Educational Research, 82(1), 5-60.

Elkhafaifi, H. (2005). Listening Comprehension and Anxiety in the Arabic language Classroom. The Modern Language Journal, 89(2), 206-220. 
Elley, B. W. (1994). The IEA Study of Reading Literacy. Achievement and Instruction in ThirtyTwo School Systems. Oxford: Pergamon Press.

Elley, B. W. (1989). Review of Research on Reading Literacy. New Zealand: University of Canterbury.

Entwisle, D. R., \& Anstone, N. M. (1994). Some practical guidelines for measuring youth's race/ethnicity and socio-economic status. Child Development, 65(6), 1521-1540.

Goldenberg, C., Rueda, R., \& August, D. (2006). Sociocultural influences on the Literacy Attainment of Language-minority Children and Youth. In D. August \& T. Shanahan (Eds.), Developing literacy in second-language learners:Report of the national literacy panel on language-minority children and youth (pp. 269318). Mahwah, NJ: Lawrence Erlbaum.

Hair, J. F., Anderson, R. E., Tatham, R. L., \& Black, W. C. (1995). Multivariate data analysis (5th edn). Upper Saddle River, NJ: Prentice Hall.

Hakuta, K., Butler, Y. G., \& Witt, D. (2000). How long does it take English learners to attain proficiency. Retrieved June 6, 2010, from http://www.cde.ca.gov/el/hakuta2.pdf

Hannon, P. (2003). Family literacy programmes. In J. L. N. Hall, \& J. Marsch (Ed.), Handbook of early childhood literacy (pp. 99-111). London, England: Sage.

Heath, S. B. (1983). Ways with words: Language, life, and work in communities and classrooms New York: Cambridge University Press.

Henderson, R. (2002, July 2-4, 2002). Student Mobility and School Literacy Performance: What Does Research Suggest for Classroom Practice? Paper presented at the Australian Indigenous Education Conference, Townsville, Queensland.
Hungi, N. (2003). Measuring School Effects Across Grades (No. 6). Adelaide.: Flinders University Institute of International Education Research Collection.

Kobayashi, M. (2002). Method Effect on Reading Comprehension Test performance text Organization and Response Format. Language Teaching, 19(2), 193-220.

Kotte, D., Lietz, P. \& Lopez, M.M. . (2006). Factors Influencing Reading Achievement in Germany and Spain: Evidence from PISA 2000.

Legato, M. J. (2005a). Why Men Never Remember and Women Never Forget. New York: Rodale.

Lesaux, N. K., Lipka, O., \& Siegel, L. S. (2006). Investigating Cognitive and Linguistic Abilities that Influence the Reading Comprehension Skill of Children from Diverse Background. Reading and Writing 19(1), 99-131.

Lietz, P. (1996). Changes in Reading Comprehension Across Cultures and Over Time. Munster/New York: Waxmann.

Ling, C. (2008). Study on affective factors on listening performance of English majors in Xinjiang Agricultural University. US-China Foreign Language, 6.

Masters, G. (1997). Literacy Standards in Australia. Sydney: Australian Council for Educational Research (ACER).

Morley, J. (1991). Listening comprehension in second/foreign language instruction. In $\mathrm{M}$. Celcemuria (Ed.), Teaching English as a secong language or foreign language (pp. 81-106). Reading, MA: Heinle.

Mullis, I. V. S., Martin, M. O., Gonzales, E. J., \& Kennedy, A. M. (2003 ). PIRLS 2001 International Report. IEA's Study of Reading 
Literacy Achievement in Primary Schools in 35 Countries. Chestnut Hill, MA: Boston College

Nyikos, M. (2008). Gender and good language learners. In C. Griffiths (Ed.), Lesson from good language learners. Cambridge: Cambridge University Press.

OECD. (2001). Knowledge and Skills for Life: First Results from PISA 2000. Paris: OECD.

OECD. (2003b). Reading for Change: Performance and Engagement Across Countries: Results from PISA 2000. Paris: OECD.

Pallardi, G. J., \& Rumberger, R. W. (2002). The Effects of School Size on Student Learning and Dropout and Transfer Rates [Electronic Version]. Retrieved February 20, 2007 from http://education.ucsb.edu/news/facultyresearch/sc hoolsize.html.

Purves, A. C. (1973). Literature Education in Ten Countries: International Studies in Education II. Stockholm: Almqvist and Wiksell.

Rintaningrum, R. (2007). Reading Literacy Achievement. Flinders University of South Australia, Adelaide.

Rintaningrum, R. (2009). An Analysis of Fifth Grade Reading Literacy Achievement at the Student Level in South Australian Government School. The International Journal of Learning, 16(9), 505525 .

Rothman, S. (1999). A Multilevel Model of Student Non-Attendance. Paper presented at the Joint annual conference of the Australian Association for Research in Education and the New Zealand Association for Research in Education (29 November-2 December 1999), Melbourne.
Saunders, W. M., \& O'Brien, G. (2006). Oral Language. In F. Genese, K. Lindholm-Leary, W. Saunders, M \& D. Christian (Eds.), Educating English language Learners: A synthesis of research evidence (pp. 14-63). Cambridge, UK: Cambridge University press.

Sellin, N. (1990). PLSPATH Version 3.01: Program Manual. Hamburg, Germany.

Sellin, N. R., \& Keeves, J. P. (1994). Path analysis with latent variables. In T. Husen \& T. N. Postlethwaite (Eds.), International Encyclopedia of Education (2 ed., pp. 4352-4359). Pergamon: Oxford.

Shiotsu, T., \& Weir, C. J. (2007). The Relative Significance of Syntactic Knowledge and Vocabulary Breadth in the Prediction of Reading Comprehension Text Performance. Language Test, 24, 99-123.

Snow, C. E., Burns, M. S., \& Griffin, P. E. (1998). Preventing reading difficulties in young children. Washington, DC: National Academy Press.

Snow, C., \& Hoefnagel-Hohle, M. (1978). The Critical Period for Language Acquisition: Evidence from language learning. Child Develiopment, 49, 11191128.

Tyre, P. (2005). Boy brains, girl brains. Newsweek, CXLVI(12), 58.

van Steensel, R., McElvany, N., Kurvers, J., \& Herppich, S. (2012). How effectife are family literacy programs? Results of a meta-analysis. American Educational Research Association, 1(81), 69-96. 